\title{
Impact of Industrial Revolution on Management Thought
}

\author{
Ayesha Gulzar ${ }^{1}$ \\ MS Management Student, School of Business \& Economics, University of Management \& \\ Technology, Lahore
}

\begin{abstract}
:
This theoretical paper traces the discourse of Western Civilization from the agrarian period to industrialization, focussing on impact of industrial revolution on the process of management thought. This paper argues that, how management thought has been influenced the era of modernism when industrial revolution spread across the Europe and the United States as during modernity materialistic ethics were developed.
\end{abstract}

Keywords: Management, Industrial Revolution, Management thought

https://doi.org/10.30537/sijmb.v2i1.85

${ }^{1}$ ayeshagluzar786@gmail.com 


\section{Introduction}

Until the early 18th Century, most people survived off the land like they had been lived off for many age group (Deane \& Cole, 1962). The era was based on undeveloped subsistence that is agriculture defined by the harvests and the seasons (Ashton, 1948). People in the early $18^{\text {th }}$ century were ruled by political and social leaders. In the next 150 years an extraordinary outburst of novel ideas and new technological innovation came up which shaped a progressively more industrial and urbanised society (Anderson, 1984; Ashton, 1948; Deane \& Cole, 1962). The shift of economy from the agrarian period towards the rapid technology and innovations was the Industrial Revolution (Alford, 1951; Ashton, 1948).

Industrial revolution refers to the set of continuous events that took place in the era mid- $17^{\text {th }}$ to mid- $18^{\text {th }}$ century (C. I. Jones, 2001). These events comprises of not only set of economic and social changes but also the technological ones (Nicholson, 2011). The industrial revolution resulted in a transition of hand work to machines which led to increase in efficiency (C. I. Jones, 2001; Nicholson, 2011). This revolution spread across the eastern parts of society and the economic adoptions accelerated (Alford, 1951).

The industrial revolution not only modernized the British economy but also the rest of the world including Western Europe and North America (Ashton, 1948). According to (Cowan, 1976; Deane \& Cole, 1962; Nicholson, 2011) industrial revolution brought many adoptions that were not rapid. Industrial revolution marks as a turning point in the history of human kind (Harley, 1993; Hindle \& Lubar, 1986; Musson \& Robinson, 1969) as it shifted the agrarian society towards the machines and technology that swept across the societies.

The effects of industrial revolution extend all over the world (Gimpel, 1977). Industrial revolution gave rise to global reorganization of production, utilization, demographic activities and international relations (Harley, 1993; C. I. Jones, 2001; Lucas, 2002). Three sectors: energy, textile and iron are known for their originality of innovation during the embryonic phase of industrial revolution (Jensen, 1993; Musson \& Robinson, 1969). As a result of industrial revolution, lengthy and costly production processes were replaced by swift and cheaper substitutes that served the basis for efficiency (Cowan, 1976; Lucas, 2002).

According to various researchers (Allen, 2009; Cowan, 1976; Komlos, 1998; Lucas, 2002; Mantoux, 2006; Mokyr, 2009) for thousands of workers who were engaged in agriculture and other traditional occupations, the new technology made no difference as they were not ready to adopt the new technology. Industrial revolution was not only the era of science, machines (Von Tunzelmann, 1995) but also an era in which there was rapid increase in population so a large numbers of mouths had to feed (Lucas, 2002; Mantoux, 2006). More and more industries 
were developed and manual work was replaced by massive machinery (Fores, 1981; Mokyr, 2009).

People who lived through industrial revolution era suffered a lot (Lucas, 2002; Mantoux, 2006). Contrary to every successful industrialist such as Richard Arkwright, there is also a list of those who became futile for one or more reasons (C. I. Jones, 2001). During industrial revolution, academic developments were made (Nicholson, 2011). The underlying logic behind industrial revolution was technology (Crafts, 1995).

In the past, management referred to knowing what you want men to do and then to monitor it in the best way (Drucker, 1998, 2009). With the lapse of time the theories of management evolved consisting of two parts as the essential of management, physical and the conceptual part (Freedman, 1992). Management is a combination of various components. According to various researchers (Alford, 1951; Drucker, 1998; Wrege \& Greenwood, 1991) management is the key to economic progress. The foundation of todays' management is built on the meaningful work of past scholars such as (Anderson, 1984; Ashton, 1948; Burrell, 1994; Drucker Peter, 1954; Drucker, 1998, 2009; Freedman, 1992).

Modernism is defined as a contemporary reflection, nature, or tradition (Anderson, 1984; $R$. Cooper \& Burrell, 1988). In particular, modernism portray the modernist association in the arts (Armitage, 2000), it is a set of cultural propensity and associated cultural arrangements which actually originated from wide-scale and comprehensive changes to Western society in the late 19th and early 20th centuries (Anderson, 1984; Armitage, 2000; Berman, 1992; Burrell, 1988, 1994). There are various factors that play an important role to outline modernism (Armitage, 2000). The factors that shaped modernism include the rapid growth of the industries accompanied by the industrial revolution (Anderson, 1984; Ashton, 1948; Burrell, 1994).

The primary objective of this paper is to review that how the process of management thought has been influenced by industrial revolution during the modernism era. Taking the lead from the concept of evolution of management process, this theoretical paper aims to focus on how industrial revolution has impacted the management thought and in this back drop raises the following research questions.

\section{1- Why there was a need of management during the industrial revolution? \\ 2- How industrial revolution revolutionized the management thought process?}

The next section will encapsulate the discussion on evolution of management thought and impact of industrial revolution on the management thought by entailing the origin of management and its advances during industrialization and modernism. 


\section{Literature Review}

\section{Origin of Management and Industrial Revolution}

The history of management is as old as that of human kind (Greenwood, 1999). Management has been around for thousands of years (Drucker, 2009). The pyramids of Egypt and the great wall of China are the perceptible evidence that projects management (Argyris, 1965; Drucker, 1998). In 1776, the milestone towards the management was laid by Adam Smith who was the first to oversee the efforts of various manufacturing techniques (Sheldrake, 2003; Van Der Aalst, Ter Hofstede, \& Weske, 2003; Wrege \& Greenwood, 1991; Wren \& Bedeian, 1994). According to Adam Smith, society would gain economic advantages, if each work assigned to worker is broken down into various tapered repetitive tasks (Hofstede, 1994; Lawler III, 1973; Light, Gunderson, \& Holling, 1995). Adam Smith focussed on the problems and concepts related to management processes to increase the motivation among workers (Frey \& Osterloh, 2002; Sheldrake, 2003).

The concept of "division of labour" introduced by Adam Smith gained admiration among the workers very rapidly (Sheldrake, 2003; Van Der Aalst et al., 2003). Adam Smith recognized that division of labour leads to efficient production (Davis \& Naumann, 1999). Responsive knowledge regarding tasks enhances the level of productivity (Rosenberg, 1965). In the mideighteenth century, the paradigm of time shifted the agricultural economy towards mechanical economy (Nicholson, 2011). The shift of economy began in Great Britain and within a few decades it spread across Western Europe and United States (Jensen, 1993). Economy started to transit from the manual processes towards the new manufacturing processes in the era from about 1760-1840 (C. Cooper \& Kaplinsky, 1989; Crafts, 1985).

According to historians, the transition towards the industries, new manufacturing processes was termed as "Industrial Revolution" (Jensen, 1993; C. I. Jones, 2001; Lucas, 2002; Mantoux, 2006; Nicholson, 2011). Literature supports the two views regarding the industrial revolution, but the more traditional view was characterized by T.S. Aston and David S. Landes (Mantoux, 2006; Nicholson, 2011). The historical events that witnessed the industrial revolution comprises a set of technological innovations and social changes that swept across the British economy (Crafts, 1985). The industrial revolution came up with a "modern" economy (Fraser, 1973). In view of various researchers (Castells \& Hall, 2009; De Vries, 1994) the technological innovation that were brought in contrast to industrial revolution became a unremitting and continuous process (C. I. Jones, 2001). Technology was the basis of industrial revolution (Stearns, 1993). Energy, textiles and iron sectors were among the rapid growing revolutionary innovations (Tapscott \& Caston, 1993). 
During the industrial revolution people found it more economical to manufacture products in factories rather than at homes (Armitage, 2000). Most of the researchers suggest that industrial revolution serves as a foremost turning point in past (Sheldrake, 2003; Van Der Aalst et al., 2003; Wren \& Bedeian, 1994). Industrial revolution nearly influenced every trait of daily life in one way or other (Berman, 1992; Burrell, 1988). It happened for the first time in history that living standards of common people began to experience constant growth (Sheldrake, 2003; Van Der Aalst et al., 2003; Wren \& Bedeian, 1994). Following the industrial revolution, need for comprehensive approach towards management thought provoked a journey to modern management (C. I. Jones, 2001; Wrege \& Greenwood, 1991).

\section{The Enlightenment period (The age of reason)}

Largely positioned around France, the age of enlightenment was the period in which the scientific awakening took place (Mokyr, 2009). In the age of enlightenment, metaphysics started to pose the existence of the objects that cannot be observed (Mokyr, 2009). In specific, the enlightenment period permitted the people to question anything. The effects of French enlightenment spread beyond the borders (Miller, 2009). Enlightenment served as a big stepping stone between the unenlightened world and today's world. The age of reason opened up the gates to novel ideas and thoughts (Dekker, 2011). The age of enlightenment was the time in which drastic changes occurred, that with the reason it has been termed as an Intellectual Revolution (Breckman, Gordon, Moses, Moyn, \& Neaman, 2011).

\section{Industrial Revolution in era of Modernism}

The period of Modernity is the era that began with the enlightenment and science (about 1687 to 1789) (Anderson, 1984). Researchers suggest that Rene Descartes (1596-1650) and later on, Immanuel Kant (1724-1804), formed the era rationally by their philosophy that through validation they could ascertain a basis of collective truths (Alford, 1951; Drucker, 2009; Freedman, 1992).

Modernism is also referred as the era of science and industries (Anderson, 1984; Armitage, 2000). From the sociological point of view, modernism refers to socio-political and scientific-philosophical realism of the Western societies (Forman, 1996). Political leaders of modernity also mastered rationale as the cause of evolution in social change, believing that logic could create a just and unrestricted social order (Ashton, 1948; Burrell, 1994; Drucker Peter, 1954).

The beliefs of leaders during the era of modernism fed the American and French Democratic revolutions, the first and second World Wars, and the thinking of many today (Crafts, 1985; B. N. Nelson, 1981). The major outcomes of modernity are democratic system, capitalism, industrialization, science, and urbanization (Allen, 2009; Smelser, 2006). The gathering flags of SIJMB $\quad P$ - ISSN: 2313-1217 E-ISSN: 2410-1885 @ 2015 Sukkur Institute of Business Administration V.2, No.1|Apr 15 
modernity are liberty and the entity (Chia, 1995; R. Cooper \& Burrell, 1988; Smelser, 2006). In the era of modernism, not only the science but industrial development had massive effects economy wide (Briggs, 2004; Grasmick, 1973).

\section{Outcomes of modernity}

Although modernity developed alongside the extensive desacralisation of social life, yet it failed to replace the religious convictions with the scientific ones (Anderson, 1984). On one side, science gave the people the possibility of increasing control over their lives, yet it failed to provide values for guidance of people's lives (Breckman et al., 2011). During modernism, privatisations resulted in increasing number of individuals left alone with the task of establishing and maintaining values for guiding their lives (R. Cooper \& Burrell, 1988).

\section{Critique of Karl Marx}

Karl Marx and Sigmund Freud also undermined the modernist belief that rationale is the basis of reality by classifying monetary services above the face of society and psychological forces below it that are not bound by reason, yet are powerful shapers of society and individuals (Featherstone, 1990). Modernity is inclined by the rationalism of Newton, Descartes, Kant, and others (Habermas, 1987). Modernists always have faith that theory can represent realism (Beck, 1992; Giddens, 1991). According to Marx, a system of capitalism where people are enforced to sell their labour in order to live is unfair (Somerville, 1934). Karl Marx disagreed with the principle of modern capitalistic economy. According to Karl Marx in contemporary modern capitalist economy the people were treated as mechanism instead of human (Marx, 2012). Marx stated that the industrially more developed country shows the less developed image of its own future (Marx, 1986).

\section{Emergence of Modern Management during Industrial revolution}

\section{Contribution of Frederick Taylor}

In the era of modernism and industrial revolution the economy transit, rapidly towards the mechanical actions and processes (Ludäscher et al., 2006). The rapid increase in the industrialization and the modernist view collectively provoked the need to improving the economic proficiency, focussing especially on labour productivity (Alford, 1951). On the basis of the classical theories of management, the foundation of scientific management was laid by Frederick W. Taylor (Aufhauser, 1973; Frederick, 1911; Freedman, 1992; Freeman \& Louçã, 2002). 
Frederick Taylor introduced the concept of scientific management that influenced the management thought process in a considerable way (G. R. Jones, George, \& Hill, 2003). Taylor found out that by the use of scientific procedures and methods, the proficiency of workers can be increased and economy can gain substantial growth (Freedman, 1992). The principles of scientific management introduced by Frederick Taylor were applied widely across the industries to increase the productivity of the organizations (Drucker, 1998; Frederick, 1911).

Various researchers suggest that Taylor's efforts unlocked the new prospects of management (Armitage, 2000; Aufhauser, 1973). Taylor created a mental revolution between the workers by outlining crystal guidelines for the improvement of production (Alford, 1951).

The principles of scientific management evolved during the embryonic phases of industrial revolution (Freeman \& Louçã, 2002; Habermas, 1987; Harley, 1993). Scientific management is considered as one of the most primitive efforts to apply science to the engineering of processes and to management (Ludäscher et al., 2006). Scientific management was one of the earliest accomplishments to analytically treat management and process advancement as a scientific delinquent (D. Nelson, 1974, 1980; Spender \& Kijne, 1996). Even though the archetypal application of scientific management was manufacturing, but the objective of scientific management was to create knowledge about how to develop the work processes (Taylor, 2013; Wrege \& Greenwood, 1991; Wren \& Bedeian, 1994).

\section{Contribution of Max Weber}

Following the work of Frederick Taylor, Max Weber worked at the subject of management from the perspective of sociology (Gouldner, 1954; Locke, 1982; Lutzker, 1982; D. Nelson, 1980; Scaff, 1981). The economic development observed by Weber in United States was quite different from those in Germany (Kilduff, 1993). The economy of U.S flourishes rapidly in contrast to Germany with large professionally managed firms during industrial revolution (Lutzker, 1982). The spirit of capitalism stimulated innovation and competition across the United States (Nassehi, 2005). Max Weber approached the phenomenon of management from a sociological perspective (Ritzer, 1975).

The contribution of Weber was a framework of characteristics which was termed as "Bureaucracy" (Joerges \& Czamiawska, 1998; Swedberg, 2000). The contribution of Max Weber towards management thought is totally bureaucratic (Fine, 1984; Joerges \& Czamiawska, 1998; Swedberg, 2000). According to Weber, the societies are getting more and more 
industrialized (Käsler, 1988). The purpose of industry creation and goals is also getting complex with the rapid innovation (Rappa, 2003). Bureaucracy suggests that the style of management should be hierarchal (Gareth Morgan, 1989) and people should obey the order of legitimate authority in order to achieve certain level of work proficiency (Rothschild-Whitt, 1979).

In view of some researchers (W. G. Bennis, 1969; Ladd, 1970; Mitzman, 1970; Tannenbaum, Kavcic, Rosner, Vianello, \& Weiser, 1977), it is often believed that bureaucracy is developed as a reaction to personal overpower. Bureaucracy is used as positive label referring to the most modern and competent method of organizing during industrial revolution (W. Bennis, 1965). The world observed by Weber was subjugated by class consciousness and nepotism (W. G. Bennis, 1966). Bureaucratic management is fabricated on the mechanism metaphor of society (Lakoff, 1993). The principles of bureaucratic management represent a similarity connecting the association amongst the division of a motorized device (Merton, 1940) and the association among places in a society (Gareth Morgan, 1982; Tsoukas, 1991). The emphasis of bureaucracy is on the legal authority (Clegg, 1990). The straggle behind the legal authority is to ensure the equivalent opportunity and treatment for all (Handel, 2003). Legal authority results in reduction of exploitation of employees (Trubek, 1972).

Organizations as machines acts as rational enterprise (Argyris, 1965; Satow, 1975). Industries are designed and prearranged to achieve predetermined goals as competently as possible, using the one best possible solutions to systematize and linear concept of cause and effect (Galbraith, 1974; G. Morgan \& Videotraining, 1997).The accomplishment of and association connecting divisions and places are intended to absolute the employment as efficiently as achievable (Alford, 1951; W. G. Bennis, 1966; Berman, 1992; Gareth Morgan, 1980). This perspective recommends clear hierarchal activities and managerial trainings designed at attaining explicit aims and goals (Lyon, 2001). The hierarchal events consist of traditional places and measures to organize and manage human employment (Lutzker, 1982).

Most of the researchers suggests that Max Weber's theory of bureaucracy has had a massive control on management practice (Du Gay, 2000; Lutzker, 1982; Lyon, 2001). Bureaucracy, in Weber's view acts a model in organizing industries (Engel, 1970). Although the bureaucratic management is struck by various criticisms (Hodgson, 2004), but still it serves to be central feature in modern societies (Blau, 1956). During the industrial revolution the bureaucratic management proposed by Weber was considered as rational and efficient (Handelman, 1981). 


\section{Impact of industrial revolution on management thought}

As entailed in the previous sections that before the industrial revolution, people were living in the agricultural era. In the agricultural era there was no technological innovation and the living standards were low. With the rapid outbreak of technology, economy shifted towards the machines and a need for management intensified. The living standards of people were raised and a drastic advancement in economy occurred. In the mid- $17^{\text {th }}$ to mid- $18^{\text {th }}$ century the era of modernism and industrial revolution progressed and changes in management thought processes triggered. Adam Smith positioned the groundwork of classical management before industrialization. Subsequently, the concept of scientific management was acquainted by Fredrick W. Taylor after industrial revolution. Succeeding to the work of Fredrick W. Taylor, Max Weber introduced the bureaucratic style of management afterwards to increase the work efficiency and reduce the exploitation of employees in the industries.

\section{Discussion}

Management today is the result of research work done by various researchers over many eras. The historical discourse of management leads us to the time where Adam Smith introduced the principles of division of labour for the first time to upsurge worker's productivity with efficiency. Similar to this line of thought, today the grounded theories of management are being used in various industries to discuss the productivity phenomenon

Management thought which is at the heart of any organizational performance is discussed in this paper. A major step towards the management advancement was taken during the industrial revolution. The history of the transformation of living state of affairs during the industrial revolution has been very argumentative, and was one of the topics that from the 1950 s to the 1980 s initiated most impassioned discussion among socio-economic researchers. A foremost innovation in the metal industries during the era of the Industrial Revolution was the substitute of woodland and other bio-fuels with coal. The development in field of technology played a vital role in motivating and accelerating the British Agricultural Revolution.

Although the unindustrialized improvement began in the centuries before the Industrial revolution. But industrial revolution served the basis in deliverance of labour from the land to work in the new industries of the 18th century. In parallel to revolution in industry progress, a series of machines became available which amplified worker's productivity and need for managing the workers.

We are of a view that the major contribution to the management thought was brought in result to development of industries during Industrialization and logic during modernism. The 
principles of management by Adam Smith posit the basis of management thought process. Later on the scientific theory proposed by Fredrick and Theory of bureaucracy brought forward by Max Weber are still practised today in industries as a model.

\section{Conclusion}

Following set of conclusions can be drawn from this study. Industrial revolution was an era in which there was rapid increase in population so a large number of mouths had to be fed. The historical events that witnessed the industrial revolution followed innovations and technology that spread not only in the British economy but also across the world. The industrial revolution originated the "modern" economy and the period of modernity furnished. The most important movements and procedures of modernity were capitalism, industrialization, science, and urbanization. The era of modernism and industrial revolution led not only to technological innovation but also to the new prospects of management. With the lapse of time, the span of management advanced. The principles of scientific management and the style of bureaucracy added significant contributions towards the management thought processes and worker's productivity during industrial revolution.

\section{Limitations}

The paper is critically focussing on the influence of industrial revolution on the management thought process in the era of modernism. The research is limited to the extent that it has not critically evaluated any other era in which the management thought is more advanced. The influence of industrialisation on management thought in this paper is also limited with the extent that assumptions presented are not empirically tested. 


\section{References}

Alford, L. P. (1951). Principles of industrial management: Ronald Press Company.

Allen, R. C. (2009). The British industrial revolution in global perspective: Cambridge University Press Cambridge.

Anderson, P. (1984). Modernity and revolution. New Left Review, 144(1), 96-113.

Argyris, C. (1965). Organization and innovation: RD Irwin.

Armitage, J. (2000). From modernism to hypermodernism and beyond. Paul Virilio: From Modernism to Hypermodernism and Beyond, 25.

Ashton, T. S. (1948). Some Statistics of the Industrial Revolution in Britain1. The Manchester School, 16(2), 214-234.

Aufhauser, R. K. (1973). Slavery and scientific management. The Journal of Economic History, 33(4), 811-824.

Beck, U. (1992). Risk society: Towards a new modernity (Vol. 17): Sage.

Bennis, W. (1965). Beyond bureaucracy. Society, 2(5), 31-35.

Bennis, W. G. (1966). Changing organizations. The Journal of Applied Behavioral Science, 2(3), 247-263.

Bennis, W. G. (1969). Organizational developments and the fate of bureaucracy. Readings in Organizational Behavior and Human Performance.

Berman, M. (1992). Why modernism still matters. Modernity and identity, 33-58.

Blau, P. M. (1956). Bureaucracy in modern society.

Breckman, W., Gordon, P. E., Moses, A. D., Moyn, S., \& Neaman, E. (2011). The Modernist Imagination: Intellectual History and Critical Theory: Berghahn Books.

Briggs, C. L. (2004). Theorizing modernity conspiratorially: Science, scale, and the political economy of public discourse in explanations of a cholera epidemic. American Ethnologist, 31(2), 164-187.

Burrell, G. (1988). Modernism, post modernism and organizational analysis 2: The contribution of Michel Foucault. Organization studies, 9(2), 221-235.

Burrell, G. (1994). Modernism, postmodernism and organizational analysis 4: The contribution of Jürgen Habermas. Organization studies, 15(1), 1-19.

Castells, M., \& Hall, P. (2009). Technopoles of the world: The making of twenty-firstcentury industrial complexes.

Chia, R. (1995). From modern to postmodern organizational analysis. Organization studies, 16(4), 579-604.

Clegg, S. (1990). Modern organizations: Organization studies in the postmodern world: Sage.

Cooper, C., \& Kaplinsky, R. (1989). Technology and development in the Third industrial revolution: Psychology Press. 
Cooper, R., \& Burrell, G. (1988). Modernism, postmodernism and organizational analysis: An introduction. Organization studies, 9(1), 91-112.

Cowan, R. S. (1976). The" Industrial Revolution" in the home: household technology and social change in the 20th century. Technology and Culture, 1-23.

Crafts, N. F. (1985). British economic growth during the industrial revolution: Clarendon Press Oxford.

Crafts, N. F. (1995). Exogenous or endogenous growth? The industrial revolution reconsidered. Journal of Economic History, 55, 745-772.

Davis, G. B., \& Naumann, J. D. (1999). Knowledge Work Productivity. EMERGING INFORMATION TECHNOLOGIES: IMPROVING DECISIONS, CO-OPERATION AND INFRASTRUCTURE, Sage, London, 343-357.

De Vries, J. (1994). The industrial revolution and the industrious revolution. Journal of Economic History, 54(2), 249-270.

Deane, P., \& Cole, W. A. (1962). British economic growth, 1688-1959: trends and structure: University Press.

Dekker, S. W. (2011). What is rational about killing a patient with an overdose? Enlightenment, continental philosophy and the role of the human subject in system failure. Ergonomics, 54(8), 679-683.

Drucker Peter, F. (1954). The practice of management: Harper \& Brothers, New York, NY.

Drucker, P. F. (1998). Management's new paradigms. Forbes Magazine, 10, 98.

Drucker, P. F. (2009). Management Rev Ed: HarperCollins.

Du Gay, P. (2000). In praise of bureaucracy: Weber-organization-ethics: SAGE Publications Limited.

Engel, G. V. (1970). Professional autonomy and bureaucratic organization. Administrative science quarterly, 12-21.

Featherstone, M. (1990). Global culture: Nationalism, globalization and modernity (Vol. 2): Sage.

Fine, G. A. (1984). Negotiated orders and organizational cultures. Annual Review of Sociology, 239-262.

Fores, M. (1981). The myth of a British industrial revolution. History, 66(217), 181-198.

Forman, P. (1996). Modern science: Late-modernity and post-modernity. Sociologija, 38(3), 445-473.

Fraser, D. (1973). The evolution of the British welfare state: a history of social policy since the Industrial Revolution: Macmillan London.

Frederick, T. (1911). The principles of scientific management: New York: Harper and Row. Freedman, D. H. (1992). Is management still a science? Harvard Business Review, 70(6), 26-\&.

Freeman, C., \& Louçã, F. (2002). As time goes by: from the industrial revolutions to the information revolution. OUP Catalogue. 
Frey, B. S., \& Osterloh, M. (2002). Successful management by motivation: Balancing intrinsic and extrinsic incentives: Springer.

Galbraith, J. R. (1974). Organization design: An information processing view. Interfaces, 4(3), 28-36.

Giddens, A. (1991). Modernity and self-identity: Self and society in the late modern age: Stanford University Press.

Gimpel, J. (1977). The medieval machine: The industrial revolution of the Middle Ages: Penguin Books.

Gouldner, A. W. (1954). Patterns of industrial bureaucracy.

Grasmick, H. G. (1973). Social change and modernism in the American South. American Behavioral Scientist, 16(6), 913-933.

Greenwood, J. (1999). The third Industrial Revolution: Technology, productivity, and income inequality. Economic Review, 35(1).

Habermas, J. (1987). The Philosophical Discoiirse of Modernity: Cambridge: Polity Press.

Handel, M. J. (2003). The sociology of organizations: Classic, contemporary, and critical readings: Sage.

Handelman, D. (1981). Introduction: the idea of bureaucratic organization. Social Analysis(9), 5-23.

Harley, C. K. (1993). Reassessing the industrial revolution: a macro view. The British industrial revolution: an economic perspective, 171-226.

Hindle, B., \& Lubar, S. D. (1986). Engines of change: The American industrial revolution, 1790-1860: Smithsonian Institution Press Washington, DC.

Hodgson, D. E. (2004). Project work: the legacy of bureaucratic control in the postbureaucratic organization. Organization, 11(1), 81-100.

Hofstede, G. (1994). Management scientists are human. Management science, 40(1), 4-13.

Jensen, M. C. (1993). The modern industrial revolution, exit, and the failure of internal control systems. the Journal of Finance, 48(3), 831-880.

Joerges, B., \& Czamiawska, B. (1998). The question of technology, or how organizations inscribe the world. Organization studies, 19(3), 363-385.

Jones, C. I. (2001). Was an industrial revolution inevitable? Economic growth over the very long run. Advances in Macroeconomics, 1(2).

Jones, G. R., George, J. M., \& Hill, C. W. (2003). Contemporary management: McGrawHill/Irwin New York.

Käsler, D. (1988). Max Weber: University of Chicago Press.

Kilduff, M. (1993). Deconstructing organizations. Academy of Management Review, 18(1), 13-31.

Komlos, J. (1998). Shrinking in a growing economy? The mystery of physical stature during the industrial revolution. Journal of Economic History, 58, 779-802. 
Ladd, J. (1970). Morality and the ideal of rationality in formal organizations. The Monist, 54(4), 488-516.

Lakoff, G. (1993). The contemporary theory of metaphor. Metaphor and thought, 2, 202251.

Lawler III, E. E. (1973). Motivation in work organizations.

Light, S. S., Gunderson, L. H., \& Holling, C. (1995). The Everglades: evolution of management in a turbulent ecosystem. Barriers and Bridges to the Renewal of Ecosystems and Institutions, 103-168.

Locke, E. A. (1982). The ideas of Frederick W. Taylor: an evaluation. Academy of Management Review, 7(1), 14-24.

Lucas, R. E. (2002). The industrial revolution: Past and future. Lectures on economic growth, 109-188.

Ludäscher, B., Altintas, I., Berkley, C., Higgins, D., Jaeger, E., Jones, M., . . . Zhao, Y. (2006). Scientific workflow management and the Kepler system. Concurrency and Computation: Practice and Experience, 18(10), 1039-1065.

Lutzker, M. A. (1982). Max Weber and the Analysis of Modern Bureaucratic Organization: Notes Toward a Theory of Appraisal. American Archivist, 45(2), 119-130.

Lyon, D. (2001). Surveillance society: Open University Press Buckingham.

Mantoux, P. (2006). The industrial revolution in the eighteenth century: An outline of the beginnings of the modern factory system in England: Taylor \& Francis US.

Marx, K. (1986). Capital: A Critique of Political Economy. The process of production of capital (Vol. 1): Progress.

Marx, K. (2012). The Essential Marx: DoverPublications. com.

Merton, R. K. (1940). Bureaucratic structure and personality. Social Forces, 18(4), 560-568. Miller, K. D. (2009). Organizational risk after modernism. Organization studies, 30(2-3), 157-180.

Mitzman, A. (1970). The iron cage: An historical interpretation of Max Weber: Transaction Books.

Mokyr, J. (2009). The Enlightened Economy: An Economic History of Britain 1700-1850: Yale University Press.

Morgan, G. (1980). Paradigms, metaphors, and puzzle solving in organization theory. Administrative science quarterly, 605-622.

Morgan, G. (1982). Cybernetics and organization theory: epistemology or technique? Human Relations, 35(7), 521-537.

Morgan, G. (1989). Creative organization theory: A resourcebook: Sage.

Morgan, G., \& Videotraining, K. I. (1997). Images of organization (Vol. 16): Wiley Online Library.

Musson, A. A. E., \& Robinson, E. (1969). Science and technology in the industrial revolution (Vol. 3): Buy this book. 
Nassehi, A. (2005). Organizations as decision machines: Niklas Luhmann's theory of organized social systems. The Sociological Review, 53(s1), 178-191.

Nelson, B. N. (1981). On the Roads to Modernity: Conscience, Science, and Civilizations: Selected Writings: Rowman \& Littlefield Pub Incorporated.

Nelson, D. (1974). Scientific management, systematic management, and labor, 1880-1915. The Business History Review, 479-500.

Nelson, D. (1980). Frederick W. Taylor and the rise of scientific management: University of Wisconsin Press Madison, WI.

Nicholson, J. (2011). The Industrial Revolution and Beyond. The Gifts of Athena: Historical Origins of the Knowledge Economy, 78.

Rappa, A. L. (2003). A Critique of Modernity: On Positivism, and Phenomenology. Alternatives: Turkish Journal of International Relations, 2(3\&4).

Ritzer, G. (1975). Professionalization, bureaucratization and rationalization: the views of Max Weber. Social Forces, 53(4), 627-634.

Rosenberg, N. (1965). Adam Smith on the division of labour: two views or one? Economica, 32(126), 127-139.

Rothschild-Whitt, J. (1979). The collectivist organization: An alternative to rationalbureaucratic models. American Sociological Review, 509-527.

Satow, R. L. (1975). Value-rational authority and professional organizations: Weber's missing type. Administrative science quarterly, 526-531.

Scaff, L. A. (1981). Max Weber and Robert Michels. American Journal of Sociology, 12691286.

Sheldrake, J. (2003). Management theory: Cengage Learning EMEA.

Smelser, N. J. (2006). Social change in the industrial revolution: An application of theory to the British cotton industry: Taylor \& Francis US.

Somerville, H. (1934). KARL MARX AND CAPITALISM. New Blackfriars, 15(168), 192202.

Spender, J.-C., \& Kijne, H. J. (1996). Scientific management: Frederick Winslow Taylor's gift to the world? : Kluwer Academic Pub.

Stearns, P. N. (1993). The industrial revolution in world history: Westview Press Boulder, CO.

Swedberg, R. (2000). Max Weber and the idea of economic sociology: Princeton University Press.

Tannenbaum, A. S., Kavcic, B., Rosner, M., Vianello, M., \& Weiser, G. (1977). Hierarchy in organizations. Nursing Administration Quarterly, 1(4), 87-88.

Tapscott, D., \& Caston, A. (1993). Paradigm Shift: The New Promise of Information Technology: ERIC.

Taylor, F. W. (2013). Scientific management: Routledge.

Trubek, D. M. (1972). Max Weber on law and the rise of capitalism. Wis. L. Rev., 720. 
Tsoukas, H. (1991). The missing link: A transformational view of metaphors in organizational science. Academy of Management Review, 16(3), 566-585.

Van Der Aalst, W. M., Ter Hofstede, A. H., \& Weske, M. (2003). Business process management: A survey: Springer.

Von Tunzelmann, G. N. (1995). Technology and Industrial Progress: the foundations of economic growth: Edward Elgar Publishing.

Wrege, C. D., \& Greenwood, R. G. (1991). Frederick W. Taylor, the father of scientific management: myth and reality: Irwin Professional Pub.

Wren, D. A., \& Bedeian, A. G. (1994). The evolution of management thought. 